\title{
PEACEFUL LIFESTYLE OR INNOCUOUS IMAGE: ISLAMIC BRANDING USING KAZAKH PROVERBS ON YOUTUBE
}

\author{
Erik Aasland
}

\begin{abstract}
The government of Kazakhstan places a high value on Kazakh oral tradition as a resource for societal restoration. At the same time, there has been a resurgence of Islam in the country and the on-going process of defining a form of Islam that is Kazakh. Asıl Arna, the state approved Islamic governing body's media company, posted a video on YouTube that affirms Kazakh oral tradition as part of a message of living from a pure heart. Such an affirmation of a local wisdom tradition is unusual for an organisation that stresses the universal, revelatory significance of Islam for right living. Hence, the author's question: Is the video designed to instruct Kazakh-speaking Muslims or is there an agenda to change societal perceptions of Islam?
\end{abstract}

Keywords: branding, Islam, Kazakhstan, proverbs, YouTube

This article ${ }^{1}$ began when I did a YouTube search using the Kazakh word maqal (proverb). After sifting through a few videos that presented Kazakh proverbs, I came across a fascinating video prepared by an Islamic broadcasting company in Kazakhstan. At the outset of this video, the narrator sings the praises of Kazakh proverbs. I was surprised because scripturally-oriented Muslim and Christian Kazakhstanis have, on occasion, warned me about putting too much stock in the truth of Kazakh proverbs. I checked other YouTube videos by this same company, Assl Arna (Precious Channel), the state approved Islamic governing body's media company. Their other videos are primarily instructional. I was left with the question: Did Assl Arna produce this video to instruct Kazakhspeaking Muslims or is there an agenda to change societal perceptions of Islam? In order to make this question understandable, we will need to consider both the religious situation in Kazakhstan and the on-going role of folklore in that context. 


\section{THE RELIGIOUS CONTEXT FOR KAZAKHS IN KAZAKHSTAN}

Kazakhs are a largely Muslim ethnic group who emphasise the values of Islam, communal celebrations as well as lifecycle rites and rituals (Omelicheva 2011). From 1993 to 2007, the percentage of Kazakhs declaring themselves as adherents to Islam increased sharply (going from $46 \%$ to nearly $75 \%$ ), but the percentage of those who faithfully keep the fast increased only slightly, from $32 \%$ to $37 \%$ (Lubin \& Joldasov 2010: 45-48).

Early in the 1990s, Kazakhstan along with other Central Asian nations expressed an interest in allowing greater freedom for Islamic groups within their borders. However, this interest waned with the rise of the Taliban in Afghanistan, threatening Kazakhstan and the events around 9/11, 2001 (Trisko 2005: 374). In May of 2011, Muslim extremists planted a bomb in the western region of Kazakhstan. These events served as the impetus for the passage of severely restrictive legislation concerning religion (Leonard 2011). This law put new limitations on all religious activity in the country. Shortly after this, the government took action to curb foreign forms of Islamic religious expression, even strongly discouraging the wearing of Arab dress by Kazakhstani women (Nazarbayev 2012). The government affirmed the principal of modesty, but directed citizens to express this value in a traditional Kazakh way.

All of these changes put Kazakhstan in the unique situation of experiencing 'Re-Islamization' (Rorlich 2003) while seeking to differentiate themselves from radical Islam and some religious forms that come across as decidedly foreign. It is within this context of seeking a Kazakh form of Islam that the video in question was developed.

\section{FOLKLORE AS A SOCIETAL AND POLITICAL RESOURCE}

Contemporary Kazakhs view proverbs as an entrustment and as the traditional resource for defining problems, making moral judgments, and suggesting remedies (Arġınbayev 1996: 94; Ġabdullıyn 1996 [1958]: 5; Tabıldıyev 2001: 17-18). Such a societal valuation helps explain government actions such as the mandate for proverb instruction for pre-kindergarten children through secondary school, and inclusion of a section on Kazakh proverbs in the university entrance exams.

During the Soviet era, folklore was a matter of on-going government interest (Paksoy 1989). Folklore was looked on as a tool for advancing political and societal agendas (Newall 1987: 131). In contemporary Kazakhstan, folklore continues to be a matter of political interest. The Kazakhstani government has looked to what it considers indigenous and historical factors to distinguish 
itself as a nation. Folklore, in the form of Kazakh proverbs, has been an integral part of this process.

\section{ISSUES OF KAZAKH IDENTITY}

For Kazakhs, both folklore and Islam are resources for identity formation. The government has grappled with each of these resources in what Herzfeld describes for nation-states in general as an effort for "ontological self-perpetuation" and "cultural fixity" (Herzfeld 2005 [1997]: 21-22). Since Kazakhs view both folklore and Islam as part of their identity, they experience both as natural and necessary complements to each other. I have encountered this perspective on the natural and necessary aspects of Kazakh identity personally. Kazakhs over the years have told me, "You have studied Kazakh oral tradition deeply - you must have become a Muslim!"

As resources for identity formation, Kazakh folklore and Islam have different things to offer. For an ethnic group with a nomadic past and contemporary geo-political situation encroached by major world powers, Islam offers Kazakhs a connection to a wider world (i.e. the Ummah). Kazakhstan's 2050 goals stress affiliation with the Ummah (Nazarbayev 2012). At the same time, Kazakh folklore provides a background and a linkage with the historical past for the Kazakhstani nation. In this same document, Kazakhstan's current tri-lingual policy is founded on historical grounds: Kazakh as resource from the distant past; Russian as resource from the near past; English as contemporary lingua franca (Nazarbayev 2012).

Such grounding in Kazakh tradition is especially significant since there is a societal frame that encourages suspicion towards things that are foreign (Nazpary 2002: 130-136). We have to go back to the early Soviet era to understand this dyad contrasting the foreign as dangerous and the indigenous as innocuous. During the Soviet era, this dynamic was present in propaganda warning against foreign capitalism (Bonnell 1997: 201-204). At that time, capitalism was contrasted with the Soviet lifestyle, with the latter being presented as the moral and harmonious way of life. After gaining independence in 1991, Kazakhstanis depicted outsiders, whether foreigners or those outside their respective region, as khitryi (cunning) (Nazpary 2002: 127-130, 169-170). In contrast to this, Central Asians during the Soviet era were stereotyped as simple and unassuming (Adams 2004: 106). Kazakh intellectuals found this stereotype to be useful. Starting in the 1960s and continuing through the 1980s, they developed an interest in searching out Kazakh ethno-history (Kudaibergenova 2013: 847). Authors realised that when writing in Kazakh and focusing on the nomadic past 
they could present matters of significance symbolically (Kudaibergenova 2013: 842). Thus, a frame of reference developed that contrasted the local nomadic tradition with foreign influences.

\section{THE TENSION BETWEEN KAZAKH PROVERBS AND ISLAM}

The relationship between Kazakh folklore and Islam is not void of challenges. During the Soviet era, there was a clear effort to de-Islamicise the Kazakhs (Schwab 2012: 175-178). This effort was carried out in part by manipulating the content of Kazakh proverb collections and secondly by affirming the ideals while ridiculing selected practices.

The premier Kazakh proverb scholar, academician Äbduäli Qaidar, estimates that there are over fifteen thousand Kazakh proverbs (Qaidar 2007). Current published collections consist of at most a few thousand Kazakh proverbs, so there are clearly proverbs left out in each collection. If we compare a proverb collection from the early twentieth century with more recently published collections, we will note differences in terms of the Islamic content of the selected proverbs. For example, Barjaqsıulı's well respected collection from 1923, which is still in use today (Barjaqsiulı 1993 [1923]) and which includes religious content such as references to God in Kazakh term Tängir as well as Islamic term Allah and even a reference to Sharia.

The relationship between Kazakh proverbs and Islam has been marked by ambivalence. On the one hand, Kazakh proverbs present Islamic ideals positively, affirming such principles as $\bar{\imath}$ mand $\imath$, the ideal of being faithful and principled (Tabildiyev 2001: 60). On the other hand, there are numerous proverbs that critique selected actions of stereotyped Muslim clerics.

\section{TO BE A KAZAKH MUSLIM IS TO AFFIRM KAZAKH PROVERBIAL WISDOM}

Earlier on in this article, I discussed how there was an assumption that one's careful study of Kazakh oral tradition would lead one to embrace Islam. At this point, I want to consider whether being a Kazakh Muslim affects one's relationship to Kazakh proverbial wisdom. There are Kazakhs who would affirm their allegiance to Islam and yet go with Kazakh proverbial wisdom if there was a point of disagreement between the two. Still, the historical example below and my personal experience has been that Kazakh adherents of scriptural Islam ${ }^{2}$ 
will side with Islamic doctrine, even if an apparent issue between the teachings of Islam and a given Kazakh proverb could be effectively explained away. ${ }^{3}$

\section{Situation \#1: Abai Kunanbayulı ${ }^{4}$}

Abai Kunanbayul wrote during the classic period of Kazakh literature from the 1850s to the beginning of the 20th century. He was familiar with Turkish, Persian, Kazakh, Russian, and Western literature. His father was a ruler of his people (bay) and Abai was trained as an orator and leader. In his writings, he frequently quotes or adapts proverbs. Kazakhs consider him as their poet laureate based on his songs, poems, and essays (Paltore \& Zhubatova \& Mustafayeva 2012). Contemporary Kazakhs often comment that Abai's writings are as relevant today as they were when he penned his thoughts.

Here is the Kazakh proverb that Abai calls into question:

Altın körse, perishte joldan tayadl.

Seeing gold, even the angel will deviate from the path.

Abai's 29th Black Word (Kunanbayulı 1918).

Abai scoffs at the proverb, declaring that angels have no need for gold. However, his main concern is that Kazakhs will use this proverb to excuse their own greed.

The proverb above is an example of hyperbole, rhetorical exaggeration to more effectively get the point across in terms of both understanding and emotion (Clinton 1977: 61). This rhetorical device does not seek to provide referentially accurate data, but rather to connect emotionally with the audience. Hyperbolic statements are flagged for further consideration. Fauconnier and Turner (2002: 332-333) refer to this specific kind of further consideration as the "unpacking principle". The incongruity of the phrase with the overall discussion indicates that the hearer or reader needs to think outside of this phrase or image to the wider meaning of the proverb. If we acknowledge that this example fits the unpacking principle, then we will affirm that the proverb is not about an angel and gold per se. Rather, the proverb is to be understood as an affirmation of human propensity to err (Kaz. pendeshilik).

In contrast, Abai concentrates on the possible negative outcome and rejects the proverb in question. Although he understands rhetorical technique, he treats the proverb as referential and therefore feels free to reject it. In contrast to Abrahams (1971), who looks at folklore as a problem-solving resource, Abai fears the disputed proverbs will serve as a source of problem-generation. 


\section{Situation \#2: The Truncated Proverb}

There is a well-known Kazakh proverb that is recorded one way in proverb collections and then used in a shortened form in everyday speech.

From proverb collections:

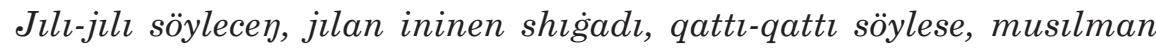
dininen shigiadl.

If you speak gentle words, the snake will be drawn out; if you speak harsh words, it will drive the Muslim from faith.

The version commonly heard in daily conversation:

Jllı-jılı söylecey, jılan ininen shigadl.

If you speak gentle words, the snake will be drawn out.

The proverb about the snake, as included in proverb collections, follows a common pattern in Kazakh proverbs of contrasting the bad and the good person (Qaidar 2004: 139). Here it recommends fitting speech based on the individual being addressed. If you address someone who is a hard person, then use gentle words to draw them out. If you address someone who is kind, then be careful not to drive them away with harsh words. Once again, here is a hyperbolic use of a metaphorical image intended to be understood figuratively. You should seek to win over the bad/crafty person with kind words and not lose the good/ innocent person because you speak harshly.

A Kazakh colleague of mine and I discussed the 'snake proverb'. She had a doctrinal concern about the person driven from faith. Although she is a literary scholar with a firm grasp of rhetorical method and hyperbole, she could not get beyond the perceived doctrinal issue.

Here is the segment of our conversation based on my best recollection:

Erik: Can you explain the proverb about the snake [the version from the proverb collection] to me?

Kazakh scholar: A Muslim cannot lose their faith permanently! This must refer to the temporary loss of faith described in the Qur'an.

Erik: I think the 'loss of faith' is meant figuratively.

Kazakh scholar: A Muslim cannot lose their faith.

Erik: That is not the point. This is clearly a hyperbolic proverb following the Kazakh proverb pattern of contrasting the bad and good person.

Kazakh scholar: It is just not right.

-- End of discussion -- 
Each of the scholars I refer to attacks the proverb in question because they view it as deviating from the truth. Proverbs as text have standing. KirshenblattGimblett points out that proverbs, from their structure, tone, and history of use within a group come across as authoritative (Kirshenblatt-Gimblett 1981 [1973]: 111). Out of respect for the power of words Kazakhs can be circumspect about hyperbolic proverbs that they question. This is especially true of those who embrace a theological, scriptural authority.

For both scholars the textual and practical aspects are linked. Abai's expressed concerns about the angel proverb address both factual and emotive significance. The contemporary Kazakh proverb scholar cannot get beyond the textual/factual issue to even consider the snake proverb as hyperbolic. Thus for the Kazakh adherent to scriptural Islam, Kazakh proverbial wisdom in general is supported, but some proverbs may be deemed unacceptable.

\section{BRANDING AND ISLAM}

'Islamic branding' has been used to describe the marketing of products to Muslims (Fischer 2012; Young 2008). However, in this article, I want to consider how Islam in Kazakhstan might be presented in a favourable light by affirming Kazakh oral tradition in a particular YouTube video. I refer to this process as branding because the aim is to have a long-standing association established about the 'product' in question. In this case, the product is Islam.

There are similar efforts underway in neighbouring Central Asian countries. Noah Tucker (2013) explores efforts by the Uzbek government to present 'Uzbek Islam' using sermons by the Mufti of Uzbekistan, the head of the stateapproved Islamic organisation. The Kazakhstan Muftiyat ${ }^{5}$ established Asıl Arna as a broadcasting company in 2007. Since then, it has developed a webpage and extended its reach through satellite broadcasting (Assl Arna 2014). Like the Muftiyat in Uzbekistan (Tucker 2013), their counterpart in Kazakhstan wants to present Islam as a peaceable religion. Making the connection between Islam and Kazakh proverbs aids them in achieving this objective.

\section{ASSESSING BRANDING IN THE VIDEO IN QUESTION}

How do we assess the use of branding in the selected video? We need to consider what is being communicated in terms of key words, metaphors, and lines of reasoning (Quinn 2005). We also need to evaluate language choice, since this both serves the self-presentation of the producers and helps define the expected 
audience. Finally, since we are talking about a video, I will consider how the settings and groups in the video situate the viewer.

I am not attempting to determine intentionality. In making the evaluation, I will be looking to the structure of the video. I will ask two questions: 1 . What are the messages communicated by the video? 2. Does the content match up with other instructional videos posted by Asıl Arna?

\section{THE STRUCTURE AND THE FLOW OF THE VIDEO}

Asıl Arna's attempt to connect Islam with Kazakh oral tradition is presented in the YouTube video titled, Din ham Dil men Til: jaqsı söz, jarım urıs (Religion, a pure heart and language: A good word is half of prosperity) (Tazabek 2013). The video was posted in March of 2013 and has been viewed six hundred and nine times as of October 3, 2014.

Overview of the video:

00:00-00:25 Islamic greeting, calligraphy 'Allah' in Arabic, calligraphy 'bismillah' (in the name of Allah) in Arabic; incorporated Kazakh pictures with 'Allah' overlay for the initial inserted video;

00:26-00:30 Kazakh proverb on Kazakh pattern slide: "A good word - half of wealth";

00:30-01:00 Kazakh historical footage with narration about how Kazakhs have passed truth and wisdom down through the ages by means of proverbs; 01:01-01:11 One of Solomon's proverbs (most likely Proverbs 16:24, but no citation is given);

01:12-02:06 Proverbial phrases and proverbs concerning the importance of right speech for passing along wisdom;

02:07-02:12 Slide "Jaqsı atı ölmeydi, galımnı .atı ölmeydi" (a good name does not die; the scholar's letter does not die);

02:12-03:27 Mullah and then a philologist speak about the power of words and the need for a pure heart as the source of good words (a scholar filmed outside the Kazakhstan Academy of Sciences);

03:28-07:08 The importance of words for setting an example;

07:08-07:19 Slide: Abai wrote to be an example to the younger generation; 07:20-10:50 Nature slide with Kazakh proverbial phrases;

Music with English lyrics in the background is "Forgive Me When I Whine", as adapted by Zain Bhirkha;

First mention of 'snake proverb' (08:12); 
10:51 Importance of good speech among Muslims;

Extensive use of Arabic with translation and quoting of Mohammed;

Second mention of the 'snake proverb' on Kazakh patterned slide (13:17);

Introduction of the theme of faithfulness using multiple forms of the same concept;Third mention of the 'snake proverb' by the narrator followed immediately by the theme proverb;

17:35 Törelik: account of Kazakh traditional, communal lifestyle;

17:55 Excommunication;

18:24 Same sequence as at the outset, but now with credits.

The video starts with an Islamic prayer of praise to God (Allah) accompanied by videos of Kazakh traditional hospitality, a yurt, and mountains. Next, the scene shifts to historical footage of the Kazakhs, accompanied by a discussion of the truth that has been passed down through Kazakh oral tradition. Then, it transitions from historical to contemporary with a short segment of a mullah preaching in a mosque and then longer comments by a philologist, each talking about Qur'anic and Kazakh proverbial instruction on how to speak with others. Each speaker utilises a mix of proverbs, aphorisms by famous Kazakhs leaders, and Islamic teaching. Next, there are nature scenes with pleasant background music along with proverbs and sayings in text form. About two-thirds of the way through there is a long segment by a Qur'anic specialist who reads sections from the Hadith (i.e. traditions concerning the life and ministry of Mohammed) and then explains them. He uses different forms of $\bar{\imath} m a n d r q$, the idea of being faithful and principled (which I discussed earlier). Finally, the video finishes with historical footage, an account of the importance of unity in the camp, followed by a discussion of those who abandoned the faith, and the same prayer to Allah with which it began.

In terms of genre, the video in question is an extended homily complete with stories and reinforcing proverbs. This classification is also supported by the settings represented in the video. Although it does show a scholar and some people in the streets, most of the footage with people is from mosques.

The primary message is the importance of $\bar{\imath}$ mand $l q$ (being principled). Still the affirmation of Kazakh proverbs as a resource for truth is also important. I will have to examine the proverbial content more closely to assess whether the primary message is consistent with other postings by this media company. 


\section{PROVERBIAL CONTENT}

The video utilises numerous Kazakh proverbs about how to speak, the importance of wisdom, and the value of silence. What stands out amidst all the proverbial content is the minimal metaphorical content of the proverbs presented in the video, and two proverbs that I will consider.

Kazakh proverbs like the proverbs from many nations are rich in metaphorical content, using references to animals, daily objects, or specific groups of individuals. The proverbs used in the video incorporate metaphors that are so common that they have lost much of their metaphorical force; for example, 'heart' for the centre of one's being or 'gold' to represent wealth in general. The proverb used in the title and then repeated three times in the video is similar: jaqsı söz, jarım urıs (a good word, half of prosperity). Thematically the proverb is an excellent fit for the topic, but it has no metaphorical content.

\section{AN ADAPTED KAZAKH PROVERB}

Another proverb is also used three times in the video, but it has more metaphorical content. It is the snake proverb that was considered earlier. Here again is the traditional form of the proverb:

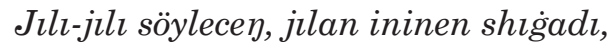
qattı-qattı söylese, musılman dininen shigiadı.

If you speak gentle words, the snake will be drawn out;

If you speak harsh words, it will drive the Muslim from his faith.

Much like the Kazakh scholar who was described earlier, the producers of the video seem uneasy about the reference to a "Muslim driven away from his faith", which is part of a traditional proverb. In two cases in which they insert the proverb, they leave off the second half. As mentioned previously, this truncated form is common in the speech of Kazakhs in Kazakhstan.

What is more interesting is their adaptation, which is presented near the middle of the video.

Adaptation:

Jılı sözden, jılan ininen da shıg்adı, Jllı sözder jurek dertin jazadı.

By gentle words the snake is drawn out;

Gentle words heal the heart. 
I could locate this variant neither in proverb collections nor online. The adapted version is missing most of the parallel construction. There is only one agent left and the two verbs at the end of each line have lost the spatial deictic contrast (drawing out versus driving away) present in the standard form. It is an acceptable adaptation, but lacks much of the original's stylistic richness. Clearly, the adaptation has been done primarily for doctrinal reasons. The reworking of the proverb indicates that while the Islamic producers of the video may warm up to Kazakh proverbs, they do so on their own terms. When a selected proverb might appear in tension with Islamic doctrine, they take liberties in shaping or reshaping the content just as other scripturally-oriented Kazakhs would. They are not altering their doctrinal position to affirm the significance of Kazakh oral tradition.

The video effectively integrates the Kazakh proverbs in order to support the overall Islamic message. Concurrently it implements proverbs with minimal metaphorical content and adjusts one proverb to ensure that there are no doctrinal issues.

\section{LIFESTYLE INSTRUCTION OR INNOCUOUS IMAGE?}

At the outset, I posed the question concerning the purpose of this video. The other videos posted on YouTube by Asıl Arna are clearly instructional videos aimed at Kazakh-speaking Muslims. This video is the only one of their postings that highlights Kazakh proverbs. As such it deserves special attention, since scriptural-oriented Kazakhs are circumspect concerning Kazakh proverbs.

The last two sections of the video before the Islamic prayer provide the answer to my question concerning the purpose. If the video primarily promoted Islamic admiration for Kazakh proverbs, there would be further examples from history of how proverbs have guided the Kazakh nation. Instead, the producers provide a section on community followed by another on excommunication with no mention of proverbs in either segment. Thus, the primary focus of the video is instruction of the faithful.

At the same time, the video presents a picture of Islam as indigenous. It affirms the historical significance of proverbs for the Kazakh people and effectively weaves proverbs into the teaching. There are modifications made to one of the key proverbs, but this follows a tradition of scripturally-oriented Kazakhs making adjustments to Kazakh proverbs on doctrinal grounds. All this is done incorporating Kazakh and Arabic with no Russian except for the Russian endings on family names in the credits. Finally, there is the scholar filmed near the Kazakhstan Academy of Sciences as the only easily recognis- 
able locale, which connects the video with Kazakh academics. These various aspects help brand the instruction as 'local', helping allay concerns of foreign aspects of some Islamic practices in Kazakhstan.

Thus, the video succeeds in accomplishing both goals. It is an instructional example to Kazakh-speaking Muslims of how to use Kazakh proverbs as a resource for practical issues of life. The key concept according to the video is imand $q$, the ideal of being faithful and principled, which was promoted even during the Soviet era. The video also presents Kazakhstani Islam as peaceful both with the theme of living from a pure heart and the multiple associations made between Islam and local traditions and language. Given the concerns about some forms used in Islam and a desire to have a Kazakh Islam, this emphasis is especially apropos. The video is a prime example of effective communication using traditional and contemporary resources in Kazakhstan's current secular, multicultural society.

\section{NOTES}

1 This article is an expanded version of a talk presented at the Western States Folklore Society Conference, University of California San Diego, La Jolla, California, on April 19, 2013.

2 I understand 'scriptural Islam' to have the position that Islam is established on the basis of universally applicable divine revelation expressed authoritatively in the Arabic Qur'an superseding any local wisdom tradition.

3 For a comparison of the scriptural and traditional approaches to Islam in Kazakhstan, see Wendell Schwab's (2012) article, "Traditions and Texts: How Two Young Women Learned to Interpret the Qur'an and Hadiths in Kazakhstan".

${ }^{4}$ Here I have decided to go with the Kazakh version of Abai's surname rather than the Russian form (Kunanbayev).

5 Council of scholars and interpreters of Islamic teaching (muftis) with the Head Mufti being a state appointee.

\section{REFERENCES}

Abrahams, Roger D. 1971. Personal Power and Social Restraint in the Definition of Folklore. The Journal of American Folklore, Vol. 84, No. 331, pp. 16-30. http:// dx.doi.org/10.2307/539730.

Adams, Laura 2004. Cultural Elites in Uzbekistan: Ideological Production and the State. In: Pauline Jones Luong (ed.) The Transformation of Central Asia: States and 
Societies from Soviet Rule to Independence. Ithaca \& London: Cornell University Press, pp. 93-119.

Arginnbayev, Halel 1996. Qazaq Otbast. [The Kazakh Family.] Almaty: Qaynar.

Asıl Arna 2014. Biz Turalı. [About Us.] Available at http://www.asylarna.kz/about/, last accessed on March 7, 2016.

Barjaqsiulı, Ahmed 1993 [1923]. Mın Bir Maqal. [One Thousand-and-One Proverbs.] Almaty: Ädebiy Kurkem Press.

Bonnell, Victoria E. 1997. Iconography of Power: Soviet Political Posters under Lenin and Stalin. Studies on the History of Society and Culture. Berkeley \& London \& Los Angeles: University of California Press.

Clinton, J. Robert 1977. Interpreting the Scriptures: Figures and Idioms. Pasadena, CA: Barnabas Resources.

Fauconnier, Gilles \& Turner, Mark 2002. The Way We Think: Conceptual Blending and the Mind's Hidden Complexities. New York: Basic Books.

Fischer, Johan. 2012. Branding Halal: A Photographic Essay on Global Muslim Markets. Anthropology Today, Vol. 28, No. 4, pp. 18-21. DOI: 10.1111/j.1467-8322.2012.00886.x.

Gabdullıyn, Mälik 1996 [1958]. Qazaq Halqının, Ayız Ädebıyeti. [Oral Literature of the Kazakh People.] Second ed. Almaty: Sanat.

Herzfeld, Michael 2005 [1997]. Cultural Intimacy: Social Poetics in the Nation-State. New York \& London: Routledge.

Kirshenblatt-Gimblett, Barbara 1981 [1973]. Toward a Theory of Proverb Meaning. In: Wolfgang Mieder \& Alan Dundes (eds.) The Wisdom of Many: Essays on the Proverb. Madison, Wisconsin: University of Wisconsin Press, pp. 111-121.

Kudaibergenova, Diana T. 2013. "Imagining Community" in Soviet Kazakhstan: An Historical Analysis of Narrative on Nationalism in Kazakh-Soviet Literature. Nationalities Papers: The Journal of Nationalism and Ethnicity, Vol. 41, No. 5, pp. 839-854. DOI:10.1080/00905992.2013.775115.

Kunanbayulı, Abai 1918. Qara Sözderi. [Black Words.] Available at http://www.abay. nabrk.kz/index.php?page=content\&id=115, last accessed on March 7, 2016.

Leonard, Peter 2011. Kazakhstan Passes Restrictive Religion Law. Yahoo! News 2011. Available at https://in.news.yahoo.com/kazakhstan-passes-restrictive-religionlaw-113803362.html, last accessed on March 7, 2016.

Lubin, Nancy \& Joldasov, Arustan 2010. Snapshots from Central Asia. Problems of Post-Communism, Vol. 57, No. 3, pp. 40-54. DOI:10.2753/PPC1075-8216570304.

Nazarbayev, Nursultan 2012. Strategy Kazakhstan-2050: New Political Course of the Established State. Astana. Available at http://www.inform.kz/eng/article/2346141, last accessed on March 4, 2016.

Nazpary, Joma 2002. Post-Soviet Chaos: Violence and Dispossession in Kazakhstan. London \& Sterling, VA: Pluto Press.

Newall, Venetia J. 1987. The Adaptation of Folklore and Tradition (Folklorismus). Folklore, Vol. 98, No. 2, pp. 131-151. DOI:10.1080/0015587X.1987.9716408.

Omelicheva, Mariya Y. 2011. Islam in Kazakhstan: A Survey of Contemporary Trends and Sources of Securitization. Central Asian Survey, Vol. 30, No. 2, pp. 243-256. DOI:10.1080/02634937.2011.567069. 
Paksoy, H.B. 1989. Alpamysh: Central Asian Identity Under Russian Rule. Hartford, CT: Association for the Advancement of Central Asian Research Monograph Series. Available at http://vlib.iue.it/carrie/texts/carrie_books/paksoy-1/, last accessed on March 7, 2016.

Paltore, Y.M. \& Zhubatova, B. \& Mustafayeva, A. 2012. Abai Kunanbayev's Role in Enrichment of the Kazakh Language. International Science Index: International Scholarly and Scientific Research \& Innovation, Vol. 6, No. 7, pp. 1934-1937. Available at http://internationalscienceindex.org/publication/8019, last accessed on March 7, 2016.

Qaidar, Äbduäli 2004. Halıq Danalığı. [Wisdom of the People.] Almaty: Toganiy T.

Qaidar, Äbduäli 2007. Personal interview, May 15.

Quinn, Naomi 2005. How to Reconstruct Schemas People Share, From What They Say. In: Naomi Quinn (ed.) Finding Culture in Talk: A Collection of Methods. New York: Palgrave Macmillan, pp. 35-82.

Rorlich, Azade-Ayse 2003. Islam, Identity and Politics: Kazakhstan 1990-2000. Nationalities Papers: The Journal of Nationalism and Ethnicity, Vol. 31, No. 2, pp. 155-176. DOI: 10.1080/00905990307127.

Schwab, Wendell 2012. Traditions and Texts: How Two Young Women Learned to Interpret the Qur'an and Hadiths in Kazakhstan. Contemporary Islam, Vol. 6, No. 2, pp. 173-197. DOI:10.1007/s11562-011-0177-4.

Tabıldıyev, Ädibay 2001. Qazaq Etnopedagogıykacı. [Kazakh Ethnopedagogy.] Almaty: Sanat.

Tazabek, Mūhamedjan 2013. Din ham Dil men Til: jaqsı söz, jarım ırıs. [Religion, a Pure Heart, and Language: A Good Word Is Half of Prosperity.] Available at http://www.youtube.com/watch?v=TzBHZJPz7kI\&noredirect=1, last accessed on March 7, 2016.

Trisko, Jessica N. 2005. Coping with the Islamist Threat: Analysing Repression in Kazakhstan, Kyrgystan and Uzbekistan. Central Asian Survey, Vol. 24, No. 4, pp. 373-389.

Tucker, Noah 2013. Uzbek Extremism in Context, Part 3: "Love Your President and Be Content With Bread, or Allah Will Give you a Disease!”. Available at http://registan. net/2013/10/14/uzbek-extremism-in-context-part-3-love-your-president-and-becontent-with-bread-or-allah-will-give-you-a-disease/, last accessed on March 7, 2016.

Young, Miles 2008. Islamic Branding: The Next Big Thing. The Wire, No. 27. Available at http://www.wpp.com/wpp/marketing/branding/islamic-branding/, last accessed on March 7, 2016. 